\title{
INFLUENCE OF STRATEGY FORMULATION DRIVERS ON STRATEGIC PERFORMANCE
}

\author{
Nwachukwu Chijioke ${ }^{1, a, *}$, Hieu Minh $\mathrm{Vu}^{2, \mathrm{~b}}$ and Fadeyi Olatunji ${ }^{3, \mathrm{c}}$ \\ ${ }^{1}$ Department of Management, Faculty of Business and Economics Mendel University in \\ Brno, Zemedelska 1, 61300, Brno, Czech Republic \\ ${ }^{2}$ Faculty of Commerce and Business Administration, Van Lang University, HCMC \\ Vietnam \\ ${ }^{3}$ Anchor University, Ayobo Ipaja, Lagos State Nigeria \\ acesogwa@yahoo.com, ${ }^{\mathrm{b}}$ hieuvu2000@gmail.com, ${ }^{\mathrm{c}}$ ofadeyi@aul.edu.ng \\ *Corresponding author
}

Cite as: Chijioke, $N ., V u, H . M .$, Olatunji, F. (2018). Influence of strategy formulation drivers on strategic performance. Ekonomicko-manazerske spektrum, 12(2), 15-25.

Available at: dx.doi.org/10.26552/ems.2018.2.15-25

\begin{abstract}
To optimize scarce resources firms, need to formulate strategies that will enable them to achieve and sustain competitive advantage. The objective of the study was to propose recommendations to managers of MNCs operating in the mobile telecommunication sector in Nigeria on how to enhance and sustain strategic performance base on the evaluation of strategy formulation drivers. The focus on company vision, mission and long-term objectives helps to bring about new insights on the impact of strategy formulation drivers on strategic performance. The study was analysed using theoretical insights from strategic management literature to better understand how strategy formulation drivers enhance strategic performance of mobile telecommunication companies in Nigeria. The authors focused on a single industry using quantitative methods and a survey to obtain information from managers of mobile telecommunication companies operating in Nigeria. One hundred and twenty managers were randomly selected from finance/audit, sales, marketing, customer service and engineering departments of the head offices and eight regional offices of four mobile telecommunication companies in Nigeria. The authors used descriptive statistics and multiple regression techniques to analyse the resultant data. Statistical package for social sciences (SPSS 25) software was employed in the different analyses conducted. The study found that strategy formulation drivers jointly influence strategic performance of mobile telecommunication firms in Nigeria. Attention to company vision and long-term objectives has significant and positive impact on strategic performance. Furthermore, attention to company mission had a negative and significant impact on strategic performance. This study contributes to the existing literature by providing experience on strategy formulation drivers and their impact on strategic performance in mobile telecommunication companies in an emerging market (Nigeria).
\end{abstract}

Keywords: strategy formulation, vision, mission, long-term objectives, strategic performance,

JEL Classification: L20, M10 


\section{Introduction}

Nowadays, intense competition, globalization, fast-changing tastes and needs of consumers are a source of concern for firms. In this context, developing appropriate strategies can allow firms adapt to such conditions and dominate the marketplace. More so, firms need to take strategic business decisions to cope with volatile and relatively unpredictable business environment. Indeed, dynamic capability enables a firm to sense, size and shape opportunities by developing and reconfiguring its resource base (Teece, 2007) to create and deliver new products and services. Strategy formulation decisions commit a firm to distinct products, resources, technologies and markets over a long period of time (David, 2011). It is a timeconsuming and complex activity performed by senior-level managers (Hamel \& Prahalad, 2010). A poorly conceived strategy may have a negative impact on the performance of organizations. Some scholars have attempted to investigate the factors that influence strategy formulation for instance, leadership and organizational environment (Rose \& Cray, 2010), culture and leadership (Siddique, 2015), leadership education level (Sije \& Ochieng, 2013), leadership skills, knowledge, academic qualification and resource limitations (Nyagah, 2015). Arguably, the understanding of firm vision, mission and establishing long-term objective are important to strategy formulation. The company vision is the guiding philosophy that demonstrates the values, purposes and direction through the mission and objectives (Finkelstein et al., 2008). The mission statement defines a firm's unique and enduring purpose (Gharleghi et al., 2011). Clearly formulated long-term objectives are important to achieve better business results. Prior studies on strategy formulation did not consider the multidimensional nature of the construct (e.g. Aremu \& Oyinloye, 2014; Wanjiru, 2016). Nonetheless, there is still more to understand about strategy formulation drivers and its impact on strategic performance, especially in the Nigerian context. In the study, we argue that company vision, company mission and long-term objectives are strategy formulation drivers. The study focuses on the mobile telecommunication sector in Nigeria. In 2016, the mobile telecommunication sector contributed $9.13 \%$ to Nigeria's Gross Domestic Product, (GDP) (Nigerian Communications Commission, 2017). The sector has attracted $\$ 35$ billion in foreign direct investment (NCC, 2017) and contributed $\$ 8.3$ billion in value added to the Nigerian economy in 2014 (GSMA, 2015). Considering the importance of formulating effective strategy, the authors seek to understand the impact of strategy formulation drivers (company vision, company mission and long-term objectives) on the strategic performance of mobile telecommunication firms in Nigeria. This research gap particularly applies to the strategic management literature on MNCs operating in the mobile telecommunication sector in Nigeria, an emerging market.

\subsection{Literature Review}

\section{Strategy Formulation and Performance}

Pearce II and Robinson Jr (2011) assert that strategy formulation help executives define their business objectives and how to accomplish those strategic objectives. Van Gelderen, Frese \& Thurik (2000) submitted that strategy formulation process and strategic plan are both important for firms to achieve competitive advantage. Strategy formulation involves assessing the strategic objectives of the organisation and deciding on the best or appropriate means to achieve the objectives (Wheelen \& Hunger, 2008). Grant (1991) asserts that strategy formulation process connects an organisation's internal resources and skills to the opportunities and risks resulting from its external environment. Empirically, Wanjiru (2016) found that strategy formulation influence performance of the hotels in Kenya. In the same 
direction, Maroa \& Muturi (2015) concluded that a significant association exists between strategy formulation and performance of flowers firms. Investigating the relationship between strategy formulation and implementation in Zimbabwe's food manufacturing industry, Katsvamutima \& Jeevananda (2014) submitted that strategy formulation and implementation improve profitability, efficiency, and competitive advantage in dynamic environments. Aremu \& Oyinloye (2014) found strategy formulation has a positive correlation with organisational performance in the Nigerian banking industry. Auka \& Langat (2016), explored the effect of strategic planning on the performance of medium-sized enterprises in Nakuru Town using strategy formulation as one of the indicators of strategic planning. It was observed that a weak positive relationship exists between strategy formulation and firm performance. The authors concluded that strategy formulation significantly influences the performance of medium size enterprises. Evidence from the literature suggests that strategy formulation exerts a positive influence on firm performance.

\subsubsection{Company Vision and Performance}

Past studies in entrepreneurship and business strategy literature underscore the importance of company vision to performance (e.g. Bird, 1992), vision communication and its impact on stories and images of the future of technology, customers, or ecosystems (e.g. Garud et al., 2014), vision content and investor perceptions of what the firm want to achieve (Cornelissen $\&$ Werner, 2014). The vision statement is an important document that communicate the goal and purpose of the firm; it must be crafted with care (Van Balen et al., 2018). Kantabutra \& Avery (2010) assert that company vision serves as a guide, re-enforce history of the company, inspire and use to control the business. Arguably, company vision should be precise and assist executives to solve current problems facing the business. A realistic vision must be relevant, motivate, inspire employees and management to focus on the prospects of the organisation. Empirically, Van Balen et al. (2018) submitted that entrepreneurs use disruptive vision to promote their innovations. Mutetei et al. (2016) observed that shared vision has a significant and positive relationship with performance. They concluded that shared vision contributed to increased performance and companies with a good understanding of their environment can solve environmental issues associated with their products and services. D' Amboise (2000) found that company vision is significantly and positively associated with sales and profits in the traditional firms, whereas such relationship does not exist for firms belonging to the new economy. Odita \& Bello (2015) found that vision dimension of strategic intent has a significant and positive relationship with organisational performance in the banking sector in Nigeria. Using correlation analysis, Kumar (2015) submitted that vision dimension of strategic planning steps has a significant and positive association with firm performance. Abu Bakar \& Zainol (2015) observed that a significant positive association exists between vision, innovation, proactiveness, risk-taking and performance of SMEs in Nigeria. Arguably, paying attention to company vision during the process of strategy formulation is very important to improve strategic performance.

H1: Attention to company vision during strategy formulation has a positive and significant influence on strategic performance.

\section{Company Mission and Performance}

David et al. (2014) submitted that the mission statement is the basis for setting priorities, strategies, plans and work assignments. Hirota et al. (2010) suggest that the mission statement has three effects: effects on reaching the goals, coordination effects, and stimulation effects. The mission statement enables a company to improve performance by using accumulated 
organisational capabilities more effectively (Hirota et al., 2010). David (2007) pointed out that a mission statement may provide very important insights about firm's customers or clients, employees, markets, technology, self-concept, desired public image, products and services, philosophy and strategies for growth and survival. Mission statement written from a customer perspective can improve customer satisfaction and firm competitive advantage (Nwachukwu \& Zufan, 2017). Studying 200 SMEs in the Gauteng province of South Africa, Sandada (2014) found that mission statements have a positive effect on the performance of SMEs. In the same direction, Mosoma (2014) investigated the impact of mission statement on the performance of four commercial banks in Tanzania. The result shows a significant relationship between the mission statement and performance of selected banks in Tanzania. Odita \& Bello (2015) concluded that the mission dimension of strategic intent has a significant and positive relationship with organisational performance in the banking industry in Nigeria. Ekpe et al. (2015) observed that firm mission is positively related to organisational performance. Studying eighteen not for profit hospitals, Forbes \& Seena (2006) found a robust evidence of the impact of mission statement on performance. However, some scholars found that the mission is not positively associated with organisational performance. For instance, in the study of Canadian businesses, Bart \& Baetz (1998) confirm, that the inclusion of financial goals within a mission statement was negatively related to performance. Arguably, this finding is difficult to explain because it is one of the few studies that reported a negative relationship between mission and performance. In the same direction, O'Gorman \& Doran, (1999) reported that no significant relationship exists between the use of comprehensive mission statements and sales growth of Irish small and medium-sized businesses. Similarly, Vandijck et al. (2007) found that there is no significant relationship between mission statements and desired employee behaviour in non-profit health care. Desmidt et al. (2011) concluded that findings on the effect of the mission statements on company performance are inconclusive and unclear. Arguably, the company mission will have a positive effect on strategic performance.

H2: attention to company mission during strategy formulation have a positive and significant impact on strategic performance.

\subsubsection{Long-term Objective and Performance}

Short-run profit maximisation is not a good approach to sustained corporate growth and profitability (Pearce II \& Robinson Jr, 2011). The organisational objective is a statement which defines what the firm wants to achieve using available resources within a specified period. Pearce II and Robinson Jr (2011) assert that executives usually set long-term objectives in seven areas; profitability, productivity, competitive position, employee development, employee relations, technological leadership and public responsibility. David (2009) notes that precise and communicated objectives are critical success factors for many reasons. First, objectives clarify the role of various stakeholders in the organisation's future. Second, objectives provide a basis for rational decision making by managers with different values and attitudes. Objectives set forth organisational priorities and convert organisation's vision and mission into precise performance targets results and outcomes (Thompson \& Strickland, 2003). Additionally, long-term objective support decision making, give shareholders a clear view of the organisation and facilitate the effective functioning of the company. Covin \& Slevin (1989) suggest that a long-term orientation, through commitment to long-term objective, improves the performance of organisations operating in an unfavourable environment. Odita \& Bello (2015) found that objectives dimension of strategic intent is the best predictor of organisational performance. Likewise, Kumar (2015) using correlation 
analysis found that goals and philosophy dimension of strategic planning steps have a significant and positive relationship with firm performance. Arguably, establishing long-term objectives will have a significant and positive influence on strategic performance.

$\boldsymbol{H 3}$ : attention to long-term objectives during strategy formulation have a positive and significant influence on strategic performance.

\section{Methodology}

\section{Participants and settings}

One hundred and twenty managers were randomly selected from finance/audit, sales, marketing, customer service and engineering departments of the head offices and eight regional offices of four mobile telecommunication companies in 2017. The participants are responsible for strategy formulation in the sample firms. Electronic survey and sending emails to respondents (Andrews et al. 2003) was used to collect information from participants. Respondents were informed that participation in the survey was voluntary and at their convenience. We assured participants that the information provided by them will be treated with utmost confidentiality.

\section{Data Collection Instrument}

The variables of the study were subjectively measured based on employee's perception. A semi-structured questionnaire was used to obtain information about the respondents' profile, company vision, company mission, long-term objectives and strategic performance. Strategy formulation drivers' measures were derived from literature review. To measure strategic performance, we adapted Santos \& Brito (2012). The questionnaire was designed in two main parts; Part A sought information about respondents' profile. Part B asked questions on company vision, company mission, long-term objectives and strategic performance. To simplify processing of the responses, the authors used a five-point Likert scale, from 1 (strongly disagree) to 5 (strongly agree) to measure strategy formulation drivers. Four questions were used to assess company vision. Four questions were used to obtain data on company mission. Three questions were used to evaluate long-term objectives. For strategic performance, participants were asked to select, among five options, from 1 (below average) to 5 (above average) which best describes the firm overall average performance compared to those of competitors in terms of customers' and employees' satisfaction, social and environmental performance based on managers' perception. We used descriptive statistics and multiple regression techniques to analyse our data. Statistical package for social sciences (SPSS 25) software was used to analyse the data collected from respondents.

\section{Model Specification}

The regression model for this study takes the form:

$$
\begin{aligned}
& Y=\beta_{0}+\beta_{1} X_{1}+\beta_{2} X_{2}+\beta_{3} X_{3}+\varepsilon \\
& \text { Where } \mathrm{Y}=\text { strategic performance } \\
& X_{1}, X_{2}, X_{3}=\text { strategy formulation drivers } \\
& X_{1}=\text { company vision. } \\
& X_{2}=\text { company mission } \\
& X_{3}=\text { Long-term objectives }
\end{aligned}
$$


$\beta 0=$ Constant or intercept which is the value of dependent variables when the independent variables is zero.

$\beta_{1}-\beta_{\mathrm{n}}=$ Regression Coefficient for independent variable.

$\varepsilon=$ error term.

\section{Reliability/Validity test}

KMO, Bartlett's test and Cronbach's alpha were used to test the validity and reliability of the constructs. Cronbach's alpha for long-term objectives (0.83), company mission (0.71), company vision (0.65), and strategic performance $(0.78)$ shows that the items are reliable and measure the variables (Zikmund et al., 2013). The KMO and Bartlett's test of sampling adequacy was significant $(\mathrm{KMO} ; 0.708, \mathrm{P}=0.000<0.05)$ and above the recommended 0.5 (Hair et al., 2010). The questionnaire items were reviewed by six strategic management scholars to ascertain face validity, comprehensiveness and coherency.

\section{Results}

$87.5 \%$ of the participants (105) completed and returned the questionnaires. $36 \%$ of the respondent's age is between 25-34 years old. Majority $62 \%$ of the respondents were between 35-44 years old. About $2 \%$ were between 45-54 years old. None of the respondents' age was 55 years and above. With respect to educational qualifications, $44 \%$ of the respondents have a first degree (HND/B.SC), $55 \%$ have a second degree (MBA/M.SC) and $2 \%$ have professional certifications. $92.4 \%$ of the respondents had worked in the firms for 5 years and above. Only $7.6 \%$ respondents had worked for the firms for less than five years. $2 \%$ of the respondents were directors, $10 \%$ were senior managers, $45 \%$ were middle managers, $41 \%$ were lower level managers, $2 \%$ were analysts and supervisors. The sample may be considered adequate in terms of the distributions of these characteristics.

Table 1: Relationship between strategy formulation drivers and strategic performance: Regression result

\begin{tabular}{|c|c|c|c|c|c|}
\hline Model & $\mathrm{R}$ & R Square & Adjusted R Square & $\begin{array}{l}\text { Std. Error of the } \\
\text { Estimate }\end{array}$ & Durbin-Watson \\
\hline 1 & $.825^{\mathrm{a}}$ & .681 & .672 & .427 & 1.447 \\
\hline
\end{tabular}

Regression result in table 1 shows that $\mathrm{R}^{2}=.681$ which implies that the three strategy formulation drivers (company vision, company mission and long-term objectives) jointly account for $68.1 \%$ variations in strategic performance of mobile telecommunication companies in Nigeria. Thus, other factors that were not examined in this study accounts for $31.9 \%$ variations in strategic performance.

Table 2: Relationship between strategy formulation drivers and strategic performance: ANOVA

\begin{tabular}{clclcll}
\hline Model & & Sum of Squares & df & Mean Square & F & Sig. \\
\hline \multirow{2}{*}{1} & Regression & 39.283 & 3 & 13.094 & 71.979 & $.000^{\mathrm{b}}$ \\
& Residual & 18.374 & 101 & .182 & & \\
& Total & 57.657 & 104 & & & \\
\hline
\end{tabular}

Source: Author's calculation

a. Dependent Variable: Strategic Performance

b. Predictors: (Constant), Long-term Objectives, Company vision, Company mission 
The ANOVA test was conducted to examine whether the regression model $\mathrm{Y}=\beta 0+\beta 1 \mathrm{X} 1+$ $\beta 2 \mathrm{X} 2+\beta 3 \mathrm{X} 3+\varepsilon$ where; $\mathrm{X} 1$ - company vision, $\mathrm{X} 2$ - company mission, $\mathrm{X} 3$ - long-term objectives (independent variables) can reliably predict strategic performance (dependent variable). Table 3 show that the linear regression $F$ test results for the multiple regression model is statistically significant $(\mathrm{F}(1,104)=71.979, \mathrm{p}=0.000)$. Based on the results it can be concluded that the independent variables as a group can reliably predict the strategic performance of mobile telecommunication firms.

Table 3: Relationship between strategy formulation drivers and strategic performance: Coefficients

\begin{tabular}{|c|c|c|c|c|c|c|c|}
\hline \multirow{2}{*}{ Model } & \multicolumn{3}{|c|}{ Unstandardized Coefficients } & \multirow{2}{*}{$\begin{array}{c}\text { Standardized } \\
\text { Coefficients } \\
\text { Beta }\end{array}$} & \multirow{2}{*}{$\mathrm{t}$} & \multirow{2}{*}{ Sig. } & \multirow[b]{2}{*}{ VIF } \\
\hline & & & Std. Error & & & & \\
\hline \multirow{4}{*}{1} & (Constant) & .528 & .370 & & 1.425 & .157 & \\
\hline & Vision & .900 & .063 & .805 & 14.309 & .000 & 1.002 \\
\hline & Mission & -.148 & .064 & -.145 & -2.304 & .023 & 1.251 \\
\hline & longterm Obj & .145 & .060 & .152 & 2.426 & .017 & 1.249 \\
\hline
\end{tabular}

Source: Author's calculation

We used the standardized coefficients (beta) (Pallant, 2007) to assess the strength of strategy formulation drivers on strategic performance. Table 4 shows company vision is the strongest predictor $(\beta=0.805, p=0.000)$, followed by long-term objectives $(\beta=0.152$, $\mathrm{p}=0.017)$. However, company mission $(\beta=-0.145, \mathrm{p}=0.023)$ has a negative significant relationship with strategic performance. In summary, $\boldsymbol{H 1}$, attention to company vision during strategy formulation has a positive significant influence on strategic performance and $\boldsymbol{H 3}$, attention to long-term objectives during strategy formulation have a positive significant influence on strategic performance are supported. $\boldsymbol{H} 2$, attention to company mission during strategy formulation have a positive significant impact on strategic performance is not supported. Thus, attention to company vision and long-term objectives exerts significant influence on strategic performance of mobile telecommunication companies. On the other hand, company mission has a negative influence on strategic performance. Table 4 reveals a variance inflation factor (VIF) ranged from 1.002 to 1.251 (<10.00) (Pallant, 2007) which suggest the absence of multi-collinearity problem. Moreover, the Durbin-Watson value of 1.447 is less than 2 , suggesting no evidence of autocorrelation.

\section{Discussion}

Strategy formulation process involves a purposeful, deliberate action to develop a firm's competitive advantage and thus improve its performance (Collis \& Montgomery, 2005). During the process of strategy formulation, it important for firms to configure their activities and resources to create value and improve performance. The findings of multiple regression analysis and ANOVA $\left(\mathrm{R}=.825, \mathrm{~F}_{(1,104)}=71.979, \mathrm{p}=0.000\right)$ show that strategy formulation drivers jointly predict strategic performance of mobile telecommunication firms in Nigeria. Further analysis in table 4 reveals that company vision is positive and significantly influence the strategic performance of mobile telecommunication firms $(\beta=0.805, p=0.000)$. Candemir \& Zalluhoglu (2013) pointed out that the vision statement shows the firm's values and aspirations which capture the heart and mind of various stakeholders. Company strategic vision provides the logical reason for future plans and strategic direction for the firm to follow to satisfy stakeholders expectations. Vision statements communicate a company strategic intent that focuses on using resources to achieve a desirable future. Vision communication motivates employees to pursue their company vision (Stam et al., 2014) which may enable 
them to create robust strategies and enhance strategic performance. Top management should involve middle and lower-level managers with respect to their strategic vision by aligning these managers with the strategy (Ateş et al., 2018). This interaction between top management, middle and lower-level managers explains strategy making (Canales, 2015). A comparative analysis of the past studies revealed that the findings of this study is in consonance with the works of several scholars who attempted to relate company vision to performance (Mutetei et al., 2016; D' Amboise, 2000; Odita \& Bello, 2015; Kumar, 2015; Abu Bakar \& Zainol, 2015). A well-defined and articulated vision is the foundation upon which a firm strategy is built on. Thus, paying attention to the company vision is important during strategy formulation because it gives strategic direction and thus, contribute positively and significantly to superior strategic performance. Therefore, it is important for mobile telecommunication firms in Nigeria to communicate and link their vision to their strategy formulation efforts, as this can make the companies develop successful strategies. Consequently, improving the performance of mobile telecommunication firms. The regression result $(\beta=-0.145, \mathrm{p}=0.023)$ in table 4 , indicate that company mission has a negative and significant impact on the strategic performance of mobile telecommunication companies in Nigeria. The negative relationship between company mission and strategic performance may be due to poor communication or employees are not aware of the company mission during strategy formulation. The results from this study negate the findings of other several researchers who found a positive and significant association between mission and organisational performance, (Sandada, 2014; Mosoma, 2014; Ekpe et al., 2015; Forbes \& Seena, 2006; Sidhu, 2003). However, the findings from this study support the previous studies that found no positive and significant relationship between mission and performance (Bart \& Baetz, 1998; O'Gorman \& Doran, 1999; Vandijck et al., 2007). The relationship between mission and performance is relatively unclear and inconsistent. Table 4 indicates that longterm objectives have a significant and positive influence on the strategic performance of mobile telecommunication firms in Nigeria. Firms need to establish long-term objectives to accomplish, devise specific strategies to grow (Grant, 1991) and achieve long-term prosperity. It is important to set appropriate long-term objectives to provide the foundation for planning, organising and decision- making. The results are consistent with some other previouslymentioned studies (Covin \& Slevin, 1989; Odita \& Bello, 2015; Kumar, 2015; Carpenter \& Sanders, 2009), who found that long-term objectives have a positive and significant impact on firm performance.

\section{Conclusion}

In the paper, we assessed the impact of strategy formulation drivers on strategic performance. The empirical study was analysed using theoretical insights from strategic management literature to better understand how strategic formulation drivers (company vision, mission and long-term objectives) enhance strategic performance. The paper concludes that attention to company vision and long-term objectives are important to achieving strategic performance. Aligning firm vision, and long-term objectives are important for companies to enhance strategic performance. Again, the study concludes that company vision dimension of strategy formulation is the major driver of strategic performance. The paper further concludes that attention to company mission during strategy formulation has a negative impact on strategic performance. The study adds to existing knowledge in the field of strategic management by exploring the connection between strategy formulation drivers and strategic performance in mobile telecommunication firms in an emerging market. The 
paper recommends that mobile telecommunication companies should pay close attention to their vision and long-term objectives during strategy formulation in order to dominate the marketplace and achieve superior strategic performance. Attention to company mission may not enhance strategic performance of the firms. To achieve sustainable strategic performance, mobile telecommunication companies' managers and employees involved in strategy formulation should be aware of their firms' vision and long-term objectives to understand the strategic direction of their firms. A good understanding of the firms' strategic direction can lead to developing effective strategies and better strategic performance. The research, however, has some limitations. First, the study focused only on mobile telecommunication firms in Nigeria. Future research may provide new insights into the subject by including other firms operating in the telecommunication industry and other sectors. The study used a single data collection method and quantitative research approach. Other researchers can use both the quantitative and qualitative approach using more than one data collection methods such as questionnaires and interviews. More so, the use of a qualitative research approach may provide a better understanding of how strategy formulation drivers impact the strategic performance of telecommunication firms. Finally, the present study focused on the direct influence of strategy formulation drivers on mobile telecommunication company's strategic performance. It may be interesting to include some mediating or moderating variables such as organizational policies, organisational structure, age and size. The addition of these variables in future research will give an in-depth understanding of the strategy formulation driversstrategic performance nexus in the telecommunication sector and other sectors.

\section{References}

Andrews, D., Nonnecke, B. \& Preece, J. (2003). Survey Design, Development and Implementation Guidelines. International Journal of Human-Computer Interaction, 16(2), 185-210.

Aremu, M.A. \& Oyinloye, O.O. (2014). Relationship Between Strategic Management and Firms' Performance in Nigerian Banking Industry. Kuwait Chapter of Arabian Journal of Business and Management Review, 4(3), $28-41$.

Ateş, N.Y., Tarakci, M., Porck, J.P., Knippenberg, D. \& Groenen, PJ. F. (2018). The Dark Side of Visionary Leadership in Strategy Implementation: Strategic Alignment, Strategic Consensus, and Commitment. Journal of Management.

Auka, D.O. \& Langat, J.C. (2016). Effects of Strategic Planning on Performance of Medium Sized Enterprises in Nakuru Town. International Review of Management and Business Research, 5(1), 188-203.

Bart, C.K. \& Baetz, M.C. (1998). The Relationship Between Mission Statements and Firm Performance: An Exploratory Study. Journal of Management Studies, 35(6), 823-854.

Bird, B. (1992). The Operation of Intentions in Time: The Emergence of the New Venture. Entrepreneurship Theory and Practice, 17, 11-20.

Canales, J.I. (2015). Sources of Selection in Strategy Making. Journal of Management Studies, 52(1), 1-31.

Candemir, A. \& Zalluhoglu, E. A. (2013). Exploring the Innovativeness and Market Orientation Through Mission and Vision Statement: The Case of Istanbul Stock Exchange Companies. Presidia- social and Behavioral Sciences, 9, 619-628.

Carpenter, M. A. \& Sanders, G. (2009). Strategic Management: A Dynamic Perspective Concepts. Upper Saddle River, NJ: Pearson International.

Collis, D.J. \& Montgomery, C.A. (2005). Corporate Strategy: A Resource Based Approach. New York: McGraw-Hill.

Cornelissen, J.P. \& Werner, M.D. (2014). Putting Framing in Perspective: A Review of Framing and Frame Analysis Across the Management and Organizational Literature. Academy of Management Annals, 8, 181235.

Covin, J.G. \& Slevin, D. (1989). Strategic Management of Small Firms in Hostile and Benign Environments. Strategic Management Journal, 10(1), 75-87.

D' Amboise, G. (2000). Vision and Objectives: A Must for Smes in The New Economy. Investigaciones Europeas de Direccióny Economía de la Empresa, 6(2), 57-64. 
David, F. (2007). Strategic Management: Concepts and Cases. Englewood Cliffs, NJ: Prentice Hall.

David, F. (2011). Strategic Management: Concepts and Cases 13th ed. Essex: Pearson Education Limited.

David, F.R. (2009). Strategic Management: Concepts And Cases. Canada: Practice Hall.

David, M.E., David, F.R. \& David, F.R. (2014). Mission Statement Theory and Practice: A Content Analysis and New Direction. International Journal of Business and Decision Sciences, 7(1), 95-109.

Desmidt, S., Prinzie, A. \& Decramer, A. (2011). Looking for the Value of Mission Statements: A Meta-Analysis of 20 Years Of Research. Management Decision, 49(3), 468-483.

Ekpe, E.O., Eneh, S.I. \& Inyang, B.J. (2015). Leveraging Organisational Performance Through Effective Mission Statement. International Business Research, 8(9), 135-141.

Finkelstein, S., Harvey, C. \& Lawton, T. (2008). Vision By Design: A Reflexive Approach to Enterprise Regeneration. Journal of Business Strategy, 29(2), 4-13.

Forbes, D. J. \& Seena, S. (2006). The Value of a Mission Statement in an Association of Not-For-Profit Hospitals. International Journal of Health Care Quality Assurance, 19(5), 400-419.

Garud, R., Schildt, H.A. \& Lant, T.K. (2014). Entrepreneurial Storytelling, Future Expectations, and the Paradox of Legitimacy. Organization Science, 25, 1479-1492.

Gharleghi, E., Nikbakht, F. \& Bahar, G. (2011). A Survey of the Relationship Between the Characteristics of Mission Statement and Organizational Performance. Research Journal of Business Management, 5(3), $117-$ 124.

Grant, R.M. (1991). The Resource-Based Theory of Competitive Advantage: Implications For Strategy Formulation. California Management Review, 23, 291-374.

GSMA. (2015). Načteno z GSMA: https://www.gsma.com/publicpolicy/wpcontent/uploads/2016/09/GSMA2015_Report_DigitalInclusionAndTheRoleOfMobileInNigeria.pdf

Hair, J., Black, W., Babin, B. \& Anderson, R. (2010). Multivariate Data Analysis 7th ed. Englewood Cliffs: Prentice Hall.

Hamel, G. \& Prahalad, C. K. (2010). Strategic Intent. Boston, MA: Harvard Business Press.

Hirota, S., Kubo, K., Miyajima, H., Hong, P. \& Park, Y. W. (2010). Corporate Mission, Corporate Policies and Business Outcomes: Evidence from Japan. Management Decision, 48(7), 1134-1153.

Kantabutra, S. \& Avery, G. C. (2010). The Power of Vision: Statements That Resonate. Journal of Business Strategy, 31(1), 37-45.

Katsvamutima, E. \& Jeevananda, S. (2014). Strategy Formulation and Implementation in Zimbabwe's Food Manufacturing Industry. International Journal of Science and Research, 3(5), 849-855.

Kumar, P. (2015). Correlation Between Strategic Planning and Firm Performance. International Journal of Management \& Business studies, 5(2), 64-75.

Maroa, J.G. \& Muturi, W. (2015). Influence of Strategic Management Practices on Performance of Floriculture Firms in Kenya. A Survey of Kiambu County Kenya. International Journal of Economics, Commerce and Management, 3(7), 497-513.

Mosoma, D. (2014). The Significance of Effective Mission Statements in Business Performance: The Case of the Banking Sector in Tanzania. European Journal of Business and Management, 6(1), 92-100.

Mutetei, T. M., Waiganjo, E. \& Mukulu, E. (2016). Impact of Shared Vision on Firm Performance of Mobile Telephone Service Providers in Kenya. International Journal of Science and Engineering Invention, 2(4), 613.

Nigerian Communications Commission. (2017). Stakeholder statistics retrived on 21-07-017 from: http://www.ncc.gov.ng/stakeholder/statistics-reports/industry-overview\#view-graphs-tables-7

Nwachukwu, C. \& Zufan, P. (2017). Influence of Customer Focused Mission Statement on Customer Satisfaction. Acta Universitatis Agriculturae et Silviculturae Mendelianae Brunensis, 65(3), 1031-1038.

Odita, A.O. \& Bello, A. (2015). Strategic intent and organizational performance: A Study of banks in Asaba, Delta State Nigeria. Information and Knowledge Management, 5(4), 60-71.

O'Gorman, C. \& Doran, R. (1999). Mission Statements in Small and Medium-Sized Businesses. Journal of Small Business Management, 37(4), 59-66.

Pallant, J. (2007). SPSS Survival Manual, a Step by Step Guide to Data Analysis Using SPSS For Windows. 3 Ed. Sydney: McGraw Hill.

Pearce, II, J.A. \& Robinson, Jr, R.B. (2011). Strategic Management: Formulation, Implementation, And Control. 12th ed. Boston, MA: McGraw-Hill Irwin.

Rose, W.R. \& Cray, D. (2010). Public-Sector Strategy Formulation. Canadian Public Administration, 53(4), 453466.

Sandada, M. (2014). Mission And Vision, Environmental Scanning and Formality of Strategic Planning as Predictors of the Performance of Small and Medium Enterprises (Smes) in the Gauteng Province of South Africa. Ecoforum, 3(2), 59-67. 
Santos, J.B. \& Brito, L.A. (2012). Toward a Subjective Measurement Model for Firm Performance. Brazilian Administrative Review, 9(6), 95-117.

Siddique, C.M. (2015). A Comparative Study of Strategic Planning Practices of SMEs and Large-Sized Business Organizations in Emerging Economies: The Case of UAE. Strategic Change, 24(6), 553-567.

Sije, A. \& Ochieng, P.A. (2013). Strategic Planning and Formulation in Public Secondary Schools, Kenya: An Empirical Study of Selected Public Schools in Homa-Bay County. International Journal of Development and Economic sustainability, 1(4), 14-22.

Stam, D., Lord, R.G., Van Knippenberg, D. \& Wisse, B. (2014). An Image of Who We Might Become: Vision Communication, Possible Selves, and Vision Pursuit. Organization Science, 25, 1172-1194.

Teece, D.J. (2007). Explicating Dynamic Capabilities: The Nature and Micro-Foundations of (Sustainable) Enterprise Performance. Strategic Management Journal, 28(13), 1319-1350.

Thompson, A.A. \& Strickland, A.J. (2003). Strategic Management: Concepts and Cases. New York: McGrawHill.

Van Balen, T., Tarakci, M. \& Sood, A. (2018). Do Disruptive Visions Pay Off? The Impact of Disruptive Entrepreneurial Visions on Venture Funding. Journal of Management Studies.

Vandijck, D., Desmidt, S. \& Buelens, M. (2007). Relevance of Mission Statements in Flemish Not-For-Profit Healthcare Organizations. Journal of Nursing Management, 15(2), 131-141

Van Gelderen, M., Frese, M. \& Thurik, R. (2000). Strategies, Uncertainty and Performance of Small Business Startups. Small Business Economics, 15, 165-181.

Wanjiru, N.S. (2016). The Influence of Strategic Management Practices on Corporate Performance of Sarova Town Hotels. Unpublished MBA Thesis, University of Nairobi, Kenya.

Wheelen, T.L. \& Hunger, J.D. (2008). Strategic Management and Business Policy 11th ed. Upper Saddle River, NJ: Pearson Prentice Hall.

Zikmund, W.G., Babin, B.J., Carr, J.C. \& Griffin, M. (2013). Business Research Methods. 9th ed. USA: SouthWestern, Cengage Learning. 